Article

\title{
Trophic State and Oxygen Conditions of Waters Aerated with Pulverising Aerator: The Results from Seven Lakes in Poland
}

\author{
Hanna Siwek $^{1, *(\mathbb{D})}$, Małgorzata Włodarczyk ${ }^{1}$ and Robert Czerniawski ${ }^{2}$ \\ 1 Department of Chemistry, Microbiology and Environmental Biotechnology, West Pomeranian University of \\ Technology Szczecin, ul J.Słowackiego 17, 71-434 Szczecin, Poland; malgorzata.wlodarczyk@zut.edu.pl \\ 2 Department of General Zoology, University of Szczecin, ul. Felczaka 3c, 71-412 Szczecin, Poland; \\ czerniawski@univ.szczecin.pl \\ * Correspondence: hanna.siwek@zut.edu.pl; Tel.: +48-914496320
}

Received: 30 November 2017; Accepted: 13 February 2018; Published: 18 February 2018

\begin{abstract}
Eutrophic lakes of all types are marked by oxygen shortage in the bottom waters during the summer season, which results in excessive release of phosphorus load. Therefore, numerous restoration activities (chemical precipitation, aeration) are being taken based on bottom-up control, which consists of limiting the nutrient pool available to lower trophic levels. The present study provides an efficiency analysis of pulverising aeration of waters in two stratified and five unstratified lakes located in Poland. The assessment was based on monitoring data (dissolved oxygen concentration (DO), \% oxygen saturation (DO\%), visibility of the Secchi disc (ZSD), the concentrations of: chlorophyll $a(\mathrm{CHL})$, total phosphorus (TP) and total nitrogen (TN)) obtained before and after installation of the aerator on the lakes. The study was conducted during the spring and the summer seasons. Throughout the study period, the stratified lakes exhibited oxygen saturation $<0.1 \%$. Having completed the restoration activities, TN:TP ratio was found to gradually increase in all analysed lakes, which indicates that aeration may decrease phosphate content in the water column. In three lakes, the ratio was $>17$, so phosphorus became the most growth-limiting nutrient. The restoration activities on four unstratified lakes had no significant effect on the changes of the Carlson trophic state indices (TSI). Either individual values of the TSI(TP), TSI(CHL) and TSI(ZSD) were comparable, or the value of TSI(TP) was higher than one or both of the remaining indices for all of the lakes.
\end{abstract}

Keywords: pulverising aeration; oxygen conditions; trophic state; lakes

\section{Introduction}

Intensification of agricultural production and global population growth has resulted in the enhanced fertility of aquatic ecosystems. The primary and most efficient method for reducing the eutrophication rate of water reservoirs is to limit or eliminate the sources of biogenic supply to lakes. In the case of highly eutrophic reservoirs, such protective actions prove to be insufficient due to the so-called "internal loading" of reservoirs when biogenic compounds accumulated over the years in the bottom sediments are introduced into the water [1-4]. Therefore, numerous restoration activities are being taken based on bottom-up control, which consists of limiting the nutrient pool—particularly phosphorus compounds-available at the lower trophic levels. The primary process of reducing phosphate ions in water is shifting the processes of phosphorus circulation at the water/sediment phase boundary to its deposition in the solid phase.

Various methods for locking phosphorus compounds in bottom sediments, as well as limiting their solubility in water, have been developed. An example of the former method is the chemical precipitation of bioavailable forms of phosphorus with the compounds of calcium $[5,6]$, 
aluminium [7-9] or iron [10-12], and the adsorption of such compounds using various kinds of sorbents, e.g., lanthanum-modified bentonite [13]. The latter group of methods comprise artificial aeration of lakes for the purpose of increasing the redox potential at the water/sediment phase boundary which, in turn, limits the release of phosphorus compounds from the bottom sediments. Artificial aeration is carried out by means of two methods: thermal destratification or hypolimnetic oxygenation while maintaining thermal stratification. The first method consists of aeration of the waters of the entire lake and is most commonly adopted during the summer stagnation period in small and deep lakes [14-16]. In aeration methods involving thermal destratification, compressed air is introduced to the waters above the bottom, at the deepest point of the lake, which results in induced rise of the water to the surface and, consequently, mixing of the water mass $[15,17,18]$. The hypolimnetic oxygenation method is used in deep lakes with thermal stratification [16,19-22]. It can be carried out using pneumatic aerators by means of injecting air or pure oxygen into hypolimnion water in a confined space and returning the oxygen-rich water to the lower layer of the lake. There are methods allowing oxygenation of the waters of shallow lakes, e.g., using the technique known as side stream supersaturation [23,24]. Another method is spraying water into air with the use of pulverising aerators. Pulverising aerators have high specific capacity, and the construction allows the use of renewable energy sources. In Poland, the most popular solution is the use of wind-driven pulverising aerators. These are distinguished by a simple design, insensitivity to changes in wind direction, and high resistance to water pollution. This technology can be used in deep lakes for the purpose of hypolimnion oxygenation, as well as in shallow lakes to eliminate the deoxygenated layer of the bottom waters (the so-called oxycline) occurring in the summer period $[25,26]$.

The aim of this study is the assessment of the effectiveness of pulverising aeration of the waters of lakes located in West Pomeranian Voivodeship. The assessment was based on monitoring data obtained before and after deployment of the aerator. Long-term effects of the use of aerators were identified by means of analysis of the changes in oxygen conditions and the trophic state of the analysed lakes during the growing season.

\section{Materials and Methods}

\subsection{The Study Lakes}

The study objects were seven lakes located in Poland, in West Pomeranian Voivodeship (Table 1). The research included two dimictic lakes with thermal stratification-Barlineckie and Zamkowe-and five unstratified lakes-Nowogardzkie, Resko Górne, Głębokie, Starzyc, Trzęsiecko. In the period 2000-2014, a wind-driven pulverising aerator was installed in each of the analysed lakes (Table 2). The aerators deployed in polymictic lakes were additionally fitted with a coagulant dose-control system. The coagulant, i.e., PIX type (main ingredient- $\left.-\mathrm{Fe}_{2}\left(\mathrm{SO}_{4}\right)_{3}\right)$, was applied in the growing season after installation of the aerator. The amount of the coagulant applied to pumped water was approximately $20 \mathrm{~kg} \mathrm{month}{ }^{-1}$. In the following years, minimum coagulant doses of $5-15 \mathrm{~kg} \mathrm{ha}^{-1}$ year $^{-1}$ were used.

Table 1. Basic morphometric parameters of the analysed lakes.

\begin{tabular}{cccccc}
\hline Lake Name & $\begin{array}{c}\text { Surface Area } \\
\left(\mathbf{1 0}^{\mathbf{3}} \mathbf{~ m}^{\mathbf{2}}\right.\end{array}$ & $\begin{array}{c}\text { Average Depth } \\
\mathbf{( m )}\end{array}$ & $\begin{array}{c}\text { Maximal } \\
\text { Depth } \mathbf{( m )}\end{array}$ & $\begin{array}{c}\text { Volume } \\
\mathbf{( 1 0}^{\mathbf{3}} \mathbf{~ m}^{\mathbf{3}} \mathbf{)}\end{array}$ & $\begin{array}{c}\text { Coastline of } \\
\text { Lake } \mathbf{( m )}\end{array}$ \\
\hline Barlineckie & 2591 & 7.2 & 18.0 & $18,579.8$ & 10,450 \\
Zamkowe & 1328 & 12.9 & 36.5 & $17,100.0$ & 10,950 \\
Resko Górne & 507 & 5.0 & 2.7 & 1358.4 & 7200 \\
Starzyc & 592 & 2.7 & 6.1 & 1580.0 & 5175 \\
Trzęsiecko & 2951 & 5.4 & 11.8 & $16,067.3$ & 15,900 \\
Głębokie & 313 & 2.4 & 6.0 & 751.0 & 3950 \\
Nowogardzkie & 983 & 5.2 & 10.9 & 5087.3 & 5700 \\
\hline
\end{tabular}


Table 2. The year of the aerator installation and mean values of dissolved oxygen saturation, TN:TP ratio for the analysed lakes in the spring and the summer season during the study years (superscript * means that only one measurement was done per season in this year).

\begin{tabular}{|c|c|c|c|c|c|c|c|c|c|}
\hline \multirow{3}{*}{ Lake } & \multirow{3}{*}{$\begin{array}{l}\text { Year of } \\
\text { Study }\end{array}$} & \multicolumn{4}{|c|}{ DO $\%$} & \multirow{2}{*}{\multicolumn{2}{|c|}{$\begin{array}{c}\text { TN:TP [mg mg }{ }^{-1} \text { ] } \\
\text { Surface Water }\end{array}$}} & \multirow{2}{*}{\multicolumn{2}{|c|}{$\begin{array}{c}\text { CHL }\left[\mathrm{mg} \mathrm{m}^{-3}\right] \\
\text { Surface Water }\end{array}$}} \\
\hline & & \multicolumn{2}{|c|}{ Surface Water } & \multicolumn{2}{|c|}{ Bottom Water } & & & & \\
\hline & & Spring & Summer & Spring & Summer & Spring & Summer & Spring & Summer \\
\hline \multirow{5}{*}{ Barlineckie } & $1994 *$ & 106.0 & 95.0 & 102.7 & $<0.1$ & 15.7 & 8.9 & 12.0 & 7.0 \\
\hline & 2000 & \multicolumn{8}{|c|}{ Aerator Installation } \\
\hline & $2001 *$ & 124.0 & 114.0 & 64.0 & $<0.1$ & 18.5 & 15.8 & 12.7 & 1.1 \\
\hline & 2010 & 108.0 & 118.0 & 11.0 & $<0.1$ & 20.8 & 26.8 & 4.0 & 4.6 \\
\hline & 2016 & 112.0 & 136.0 & 90.0 & $<0.1$ & 22.6 & 31.0 & 9.8 & 4.4 \\
\hline \multirow{4}{*}{ Zamkowe } & $1995 *$ & 94.9 & 101.4 & 93.4 & 4.8 & 2.7 & 3.1 & 5.3 & 2.3 \\
\hline & 2002 & \multicolumn{8}{|c|}{ Aerator Installation } \\
\hline & 2010 & 73.0 & 101.0 & 49.0 & 1.0 & 3.7 & 12.4 & 24.2 & 72.6 \\
\hline & $2015 *$ & 94.1 & 88.5 & $<0.1$ & $<0.1$ & 7.8 & 10.4 & 56.2 & 15.0 \\
\hline \multirow{4}{*}{ Resko Górne } & $1994 *$ & 91.4 & 104.0 & 72.5 & 53.3 & 17.1 & 4.6 & 4.5 & 74.3 \\
\hline & 2003 & \multicolumn{8}{|c|}{ Aerator Installation } \\
\hline & 2010 & 117.0 & 50.0 & 117.0 & 0.9 & 17.0 & 8.8 & 22.6 & 31.4 \\
\hline & $2015 *$ & 48.1 & 103.0 & 44.2 & 103.0 & 13.2 & 14.2 & 9.3 & 65.6 \\
\hline \multirow{4}{*}{ Starzyc } & $1997 *$ & 139.0 & 126.0 & 152.2 & 101.0 & 15.6 & 7.5 & 42.2 & 58.9 \\
\hline & 2003 & \multicolumn{8}{|c|}{ Aerator Installation } \\
\hline & 2010 & 114.0 & 118.0 & 44.0 & 71.0 & 15.3 & 14.8 & 26.8 & 42.1 \\
\hline & 2016 & 98.7 & 135.0 & 97.9 & 118.0 & 22.1 & 10.4 & 21.4 & 74.7 \\
\hline \multirow{6}{*}{ Trzęsiecko } & $2000 *$ & 105.0 & 82.2 & 99.4 & 1.0 & 36.2 & 14.1 & 15.2 & 17.0 \\
\hline & 2004 & \multicolumn{8}{|c|}{ Aerator Installation } \\
\hline & 2008 & 95.9 & 101.0 & 90.2 & 0.6 & 33.9 & 33.5 & 9.7 & 11.7 \\
\hline & 2010 & 98.0 & 132.0 & 67.0 & 1.0 & 31.7 & 21.5 & 30.9 & 23.3 \\
\hline & 2011 & 150.0 & 111.0 & 71.0 & 3.0 & 79.4 & 25.0 & 20.8 & 13.4 \\
\hline & 2016 & 118.0 & 70.1 & 6.4 & 13.6 & 31.6 & 8.5 & 9.4 & 32.3 \\
\hline \multirow{3}{*}{ Głębokie } & $2001 *$ & 125.0 & 89.2 & 134.2 & 111.0 & 17.2 & 4.5 & 42.4 & 9.7 \\
\hline & 2008 & \multicolumn{8}{|c|}{ Aerator Installation } \\
\hline & 2010 & 107.0 & 129.0 & 77.6 & $<0.1$ & 20.6 & 27.5 & 9.8 & 6.4 \\
\hline \multirow{5}{*}{ Nowogardzkie } & $1997^{*}$ & 109.0 & 42.1 & 108.1 & 43.1 & 6.1 & 3.0 & 16.0 & 19.1 \\
\hline & $2005^{*}$ & 160.0 & 151.0 & 61.6 & $<0.1$ & 8.9 & 5.2 & 37.2 & 57.5 \\
\hline & 2009 & 151.0 & 87.0 & 79.0 & 1.0 & 5.4 & 2.7 & 9.8 & 6.4 \\
\hline & 2014 & \multicolumn{8}{|c|}{ Aerator Installation } \\
\hline & $2015 *$ & 86.6 & 80.5 & 1.0 & $<0.1$ & 25.0 & 5.5 & 12.2 & 20.3 \\
\hline
\end{tabular}

\subsection{Aeration of the Lakes}

Pulverising aerators operate by taking up the bottom waters of a reservoir and dispersing it in the pulverising sector of the aerator, located on the surface of a lake, which is followed by the return of the water to the layer of the lake from which it was collected. The bottom water is taken up to the pulverising sector through hoses due to the rotation of a paddle wheel indirectly driven by a Savonius vertical-axis wind turbine. During the rotation of the paddle wheel, the water is heavily dispersed in atmospheric air, freed of volatile products of anaerobic decomposition and aerated. The oxygenated water is returned to the hypolimnion zone as a result of the force of gravity through the delivery hoses $[25,26]$. The aerators operate continuously, except when ice cover appears on the Lake. The aerators have the following characteristics: height $8 \mathrm{~m}$, raft diameter $10 \mathrm{~m}$, water output $200-800 \mathrm{~m}^{3}$ a day, water aeration increase by 3-5 times [27]. One aerator was in operation at each of the lakes. Most of them were equipped with a coagulant dosing system. The exceptions were the Barlinek and Zamkowe stratified lakes, where the aerators were employed without this system. 


\subsection{Research Methods}

The study was conducted in selected years-different for individual lakes (Table 2)—before and after installation of the aerator, during the period from 1994 to 2016 . The analysis was performed at representative points (the deepest points of the lakes) and included measurements of temperature, dissolved oxygen concentration (DO) and \% oxygen saturation (DO\%), measured with a multi-parameter elektrochemical probe [28] throughout the range from $1 \mathrm{~m}$ below the water table to the bottom, with measurements being taken every $1 \mathrm{~m}$. On the surface layer, the visibility of the Secchi disc (ZSD) was measured. One meter below the water table, the following concentrations were measured: chlorophyll $a(\mathrm{CHL})$, total phosphorus (TP), and total nitrogen (TN), by means of spectrophotometry methods: CHL with acetone as extraction solvent, TP by molybdenum method after mineralization to orthophosphates in nitric and sulfuric acid, and TN calculated as sum of nitrite nitrogen, which was measured with sulphanilic acid and 1-naphtylamine; nitrate nitrogen was measured with sodium salicylate, and total nitrogen with the use of Kjeldahl method [29]. The study was conducted 2-4 times in a year during the spring (April-June) and the summer (July-September) season in accordance with the then-applicable Regulations of the Ministry for the Environment on the methods of conducting environmental monitoring.

For the purpose of assessment of trophic changes occurring in the analysed lakes, the ratio of total nitrogen to total phosphorus (TN:TP) was calculated for the results obtained in the summer season. On the basis of this ratio, the elements limiting growth of phytoplankton biomass were identified. At TN:TP below 10, nitrogen limits growth. For ratios above 17, phosphorus is the most growth-limiting nutrient. In the range 10-17, one or both of these elements limit the growth [30]. Moreover, the trophic state of the analysed lakes was determined with the use of Carlson's Trophic State Indices (TSI); TSI(TP) and TSI(CHL) were calculated based on the summer mean ZSD, TP and CHL values [31].

The differences between the annual mean TSI values for individual lakes were analysed with the use of one-way analysis of variance following the assessment of the distribution of the analysed contents against their normal distribution (Shapiro-Wilk's test) and the test for homogeneity of variances (Levene's test). The results of the tests show the lack of grounds for the exclusion of the hypothesis on normality and homogeneity of the analysed data. The significance of the differences between mean contents of the analysed elements was assessed with the use of Tukey's post-hoc test. All statistical alayses were conducted at the significance level $\alpha=0.05$.

\section{Results}

In the surface water of all analysed lakes, DO\% was high throughout the growing season (Table 2). In the spring season, Lake Resko Górne and Lake Zamkowe exhibited the lowest values of DO\% which, on average, amounted to $85.5 \%$ and $87.3 \%$ respectively. The highest DO $\%$ was found in Lake Nowogardzkie- $126.8 \%$ on average. In the summer season, mean $\mathrm{DO} \%$ in the analysed lakes ranged from $86.0 \%$ in Lake Resko Górne to $126.1 \%$ in Lake Starzyc. In most of the analysed lakes, installation of the aerator resulted in an increase of $\mathrm{DO} \%$ in the summer season, with the exception of the following lakes: Resko Górne, Zamkowe and Nowogardzkie, where the values of the said parameter were found to decrease.

In the summer season, the bottom waters of the stratified lakes showed no improvement in oxygen conditions; in both lakes, $\mathrm{DO} \%$ was $<0.1 \%$ (Table 2). The low $\mathrm{DO} \%$ was also found in two unstratified lakes: Głębokie and Nowogardzkie. Oxygen profiles (Figure 1), which were identified on the basis of the results obtained before and after undertaking the remediating activities, were very similar in the individual lakes. In stratified lakes, the improving oxygen conditions were found only in the surface layer to a depth of approximately $5 \mathrm{~m}$. In unstratified lakes, the increased DO in the bottom waters was found only in Lake Nowogardzkie at a depth of 7-9 $\mathrm{m}$. In the remaining cases, aeration either had no effect on the oxygen profiles of the analysed lakes, or it was found that DO deteriorated after installation of the aerator. 
Lake Barlineckie

Dissolved oxygen $\left[\mathrm{mg} \mathrm{dm}^{-3}\right.$

$\begin{array}{lllllll}0 & 2 & 4 & 6 & 8 & 10 & 12\end{array}$

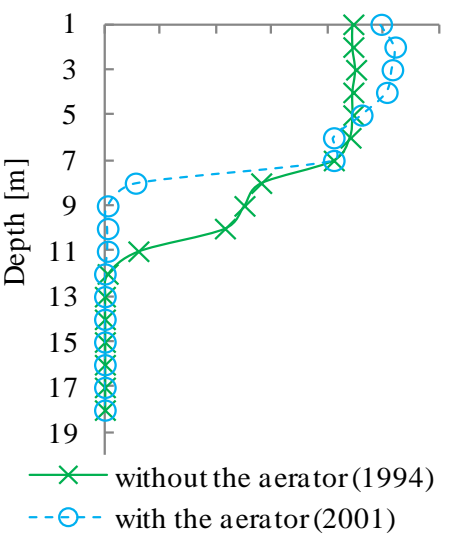

Lake Resko Górne

Dissolved oxygen $\left[\mathrm{mg} \mathrm{dm}^{-3}\right]$
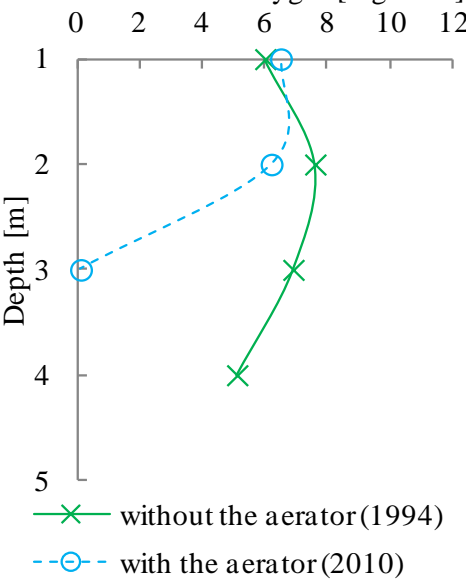
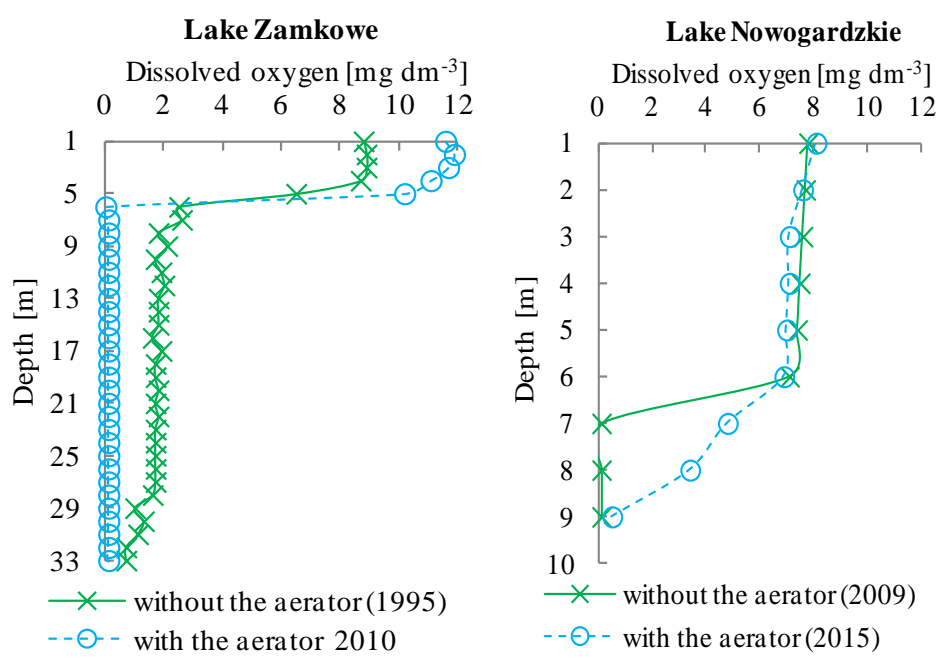

Lake Starzyc

Dissolved oxygen $\left[\mathrm{mg} \mathrm{dm}^{-3}\right]$
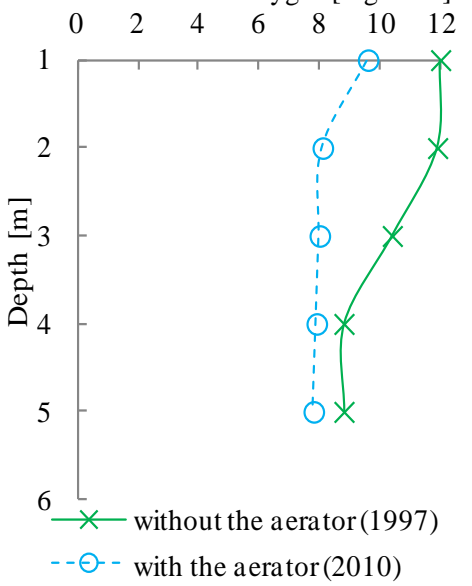

Lake Głębokie

Dissolved oxygen $\left[\mathrm{mg} \mathrm{dm}^{-3}\right]$

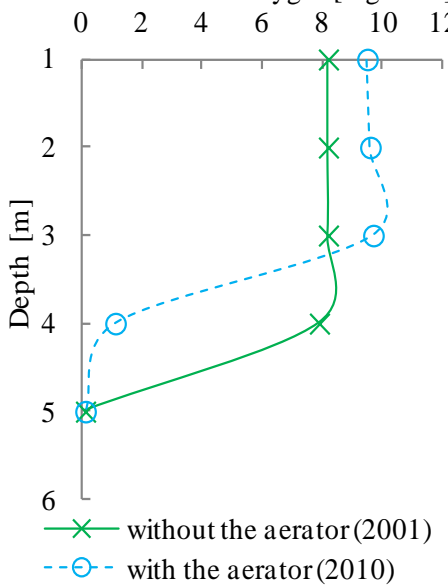

Lake Trzęsiecko

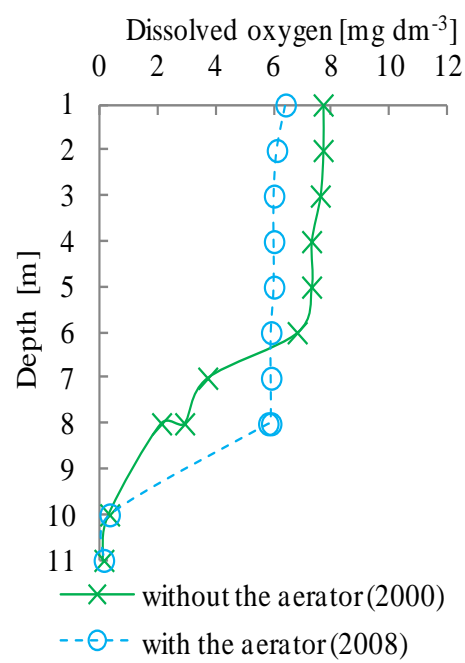

Figure 1. Example vertical profile of dissolved oxygen concentration in the water column at the deepest site of the lakes, in the summer season, before and after installation of the aerator.

In the analysed lakes, the lowest development of phytoplankton biomass was found in Lake Barlineckie; the mean CHL content calculated for all the analysed years amounted to $6.0 \mathrm{mg} \mathrm{m}^{-3}$. The highest biomass development was found in Lake Starzyc, with a mean of $44.3 \mathrm{mg} \mathrm{m}^{-3}$. In most of 
the analysed lakes, in the summer season, before deployment of the aerator, the TN:TP ratio was $<10$ (Table 2), which shows that nitrogen was the the most growth-limiting nutrient. The exception was lake Trzesiecko, where the TN:TP ratio amounted to 14.1. Having installed the aerator, the TN:TP ratio was found to gradually increase in all the lakes.

The values of the indices TSI(ZSD) and TSI(CHL) ranged from 50-70 (Table 3), which classifies the analysed lakes as exhibiting a eutrophic state, whereas the values of the TSI(TP) index in most of the analysed lakes was $>70$, which classifies the lakes as hypertrophic. The exception was Lake Barlineckie, in which the values of TSI(ZSD) and TSI(CHL) were $<50$, which classifies the lake as mesotrophic. Additionally, in Lake Barlineckie, TSI(TP) values ranged from 50-70, which indicates that the lake is eutrophic in nature. The greatest improvement in the trophic state after installation of the aerator was found in Lake Resko Górne-TSI decreased on average by $21 \%$. Testing for significance of difference between annual mean TSI values for individual lakes (Table 3) showed that in the unstratified lakes there were no significant changes in TSI after restoration activities. The exception was in Lake Resko Górne, in which there was a significant decrease in TSI(TP) and TS(ZSD). In the stratified lakes-Barlineckie and Zamkowe - there was a significant change in TSI(TP) and TS(CHL). However, in the case of Lake Barlineckie, the values of both indices decreased, whereas in the case of Lake Zamkowe only TSI(TP) showed some decrease, and the values of the TSI(CHL) index increased.

Table 3. Mean values of Carlson's Trophic State Indices: TSI(SD), TSI(TP), TSI(CHL) of the tested lakes, calculated for the individual years of the research. Different letters $(a, b, c . .$.$) indicate significant$ differences between means TSI for the entire study period $(\alpha=0.05)$.

\begin{tabular}{|c|c|c|c|c|c|}
\hline Lake & $\begin{array}{c}\text { Aerator } \\
\text { Installation }\end{array}$ & Year of Study & TSI(ZSD) & TSI(TP) & TSI(CHL) \\
\hline \multirow{4}{*}{ Barlineckie } & before & 1994 & $35.0^{\mathrm{a}}$ & $68.5^{a}$ & $46.8^{a}$ \\
\hline & \multirow{3}{*}{ after } & 2001 & $34.8^{\mathrm{a}}$ & $60.5^{b}$ & $31.5^{b}$ \\
\hline & & 2010 & $41.8^{\mathrm{a}}$ & $56.3^{\mathrm{cb}}$ & $38.2^{c}$ \\
\hline & & 2016 & $39.9^{\mathrm{a}}$ & $53.1 \mathrm{dc}$ & $45.0^{\mathrm{ca}}$ \\
\hline \multirow{3}{*}{ Zamkowe } & before & 1995 & $50.6^{a}$ & $92.3^{a}$ & $43.1^{\mathrm{a}}$ \\
\hline & \multirow[b]{2}{*}{ after } & 2010 & $59.9^{a}$ & $72.5^{b}$ & $71.4^{\mathrm{b}}$ \\
\hline & & 2015 & $53.7^{\mathrm{a}}$ & $78.1^{\mathrm{c}}$ & $63.6^{c}$ \\
\hline \multirow{3}{*}{ Resko Górne } & before & 1994 & $61.5^{a}$ & $99.7^{a}$ & $75.0^{a}$ \\
\hline & \multirow{2}{*}{ after } & 2010 & $77.3^{b}$ & $71.5^{b}$ & $64.0^{\mathrm{a}}$ \\
\hline & & 2015 & $59.4^{\mathrm{a}}$ & $76.2^{c}$ & $62.1^{\mathrm{a}}$ \\
\hline \multirow{3}{*}{ Starzyc } & before & 1997 & $60.9^{a}$ & $86.9^{a}$ & $70.5^{a}$ \\
\hline & \multirow{2}{*}{ after } & 2010 & $65.7^{\mathrm{ab}}$ & $76.3^{a}$ & $66.1^{\mathrm{a}}$ \\
\hline & & 2016 & $72.4^{b c}$ & $78.9^{a}$ & $72.9^{a}$ \\
\hline \multirow{5}{*}{ Trzęsiecko } & \multirow[t]{2}{*}{ before } & 2000 & $51.0^{a}$ & $73.7^{a}$ & $55.2^{a}$ \\
\hline & & 2008 & $51.8^{\mathrm{a}}$ & $66.8^{\mathrm{ab}}$ & $53.2^{\mathrm{a}}$ \\
\hline & \multirow{3}{*}{ after } & 2010 & $58.1^{\mathrm{b}}$ & $65.2^{b c}$ & $61.4^{\mathrm{a}}$ \\
\hline & & 2011 & $54.7^{\mathrm{ab}}$ & $66.3^{\mathrm{ca}}$ & $56.4^{a}$ \\
\hline & & 2016 & $54.7^{\mathrm{ab}}$ & $65.4^{\mathrm{ca}}$ & $58.6^{\mathrm{a}}$ \\
\hline \multirow{2}{*}{ Głębokie } & before & 2001 & $56.8^{a}$ & $58.9^{a}$ & $52.8^{a}$ \\
\hline & after & 2010 & $55.5^{\mathrm{a}}$ & $67.2^{\mathrm{b}}$ & $61.1^{\mathrm{a}}$ \\
\hline \multirow{4}{*}{ Nowogardzkie } & \multirow{3}{*}{ before } & 1997 & $93.1^{\mathrm{a}}$ & $93.1^{\mathrm{a}}$ & $65.3^{\mathrm{ad}}$ \\
\hline & & 2005 & $60.0^{\mathrm{a}}$ & $84.8^{\mathrm{a}}$ & $70.1^{\text {ba }}$ \\
\hline & & 2009 & $50.9^{b}$ & $80.8^{a}$ & $53.6^{c}$ \\
\hline & after & 2015 & $51.1^{\mathrm{b}}$ & $74.3^{\mathrm{a}}$ & $57.6^{\mathrm{dc}}$ \\
\hline
\end{tabular}

Comparison of the particular indices values shows that TSI(TP) $>$ TSI $($ CHL $)=$ TSI(SD) for most of the analysed lakes (Table 4). The exceptions were lakes Resko Górne and Głębokie, where no significant differences between the values of these indices were found. 
Table 4. Mean values of Carlson's Trophic State Indices: TSI(SD), TSI(TP), TSI(CHL) of the tested lakes calculated for the entire study period. Different letters $(a, b)$ indicate significant differences between the mean TSIs calculated for the individual lake $(\alpha=0.05)$.

\begin{tabular}{cccc}
\hline Lake & TSI(CHL) & TSI(ZSD) & TSI(TP) \\
\hline Barlineckie & $41.7 \pm 6.7^{\mathrm{a}}$ & $38.6 \pm 3.4^{\mathrm{a}}$ & $58.7 \pm 6.1^{\mathrm{b}}$ \\
Zamkowe & $59.4 \pm 9.5^{\mathrm{a}}$ & $54.7 \pm 4.7^{\mathrm{a}}$ & $81.0 \pm 9.2^{\mathrm{b}}$ \\
Resko Górne & $67.0 \pm 6.9^{\mathrm{a}}$ & $66.1 \pm 9.8^{\mathrm{a}}$ & $82.5 \pm 9.1^{\mathrm{a}}$ \\
Starzyc & $70.1 \pm 2.8^{\mathrm{a}}$ & $67.2 \pm 5.0^{\mathrm{a}}$ & $80.8 \pm 4.1^{\mathrm{b}}$ \\
Trzęsiecko & $56.9 \pm 3.1^{\mathrm{a}}$ & $54.0 \pm 2.8^{\mathrm{a}}$ & $67.5 \pm 3.5^{\mathrm{b}}$ \\
Głębokie & $56.7 \pm 4.2^{\mathrm{a}}$ & $57.3 \pm 2.0^{\mathrm{a}}$ & $62.9 \pm 4.1^{\mathrm{a}}$ \\
Nowogardzkie & $61.7 \pm 7.4^{\mathrm{a}}$ & $55.1 \pm 4.7^{\mathrm{a}}$ & $83.3 \pm 7.8^{\mathrm{b}}$ \\
\hline
\end{tabular}

\section{Discussion}

Multiannual study of seven eutrophic lakes that underwent restoration by means of pulverising aeration did not show changes in oxygen conditions of the bottom waters in either stratified or unstratified lakes. The two stratified lakes, as well as two of the unstratified lakes under analysis, showed mean DO in the bottom waters $<1 \mathrm{mg} \mathrm{dm}^{-3}$ in summer throughout the study period. This indicates hypoxia, with a threshold concentration value of dissolved oxygen $2 \mathrm{mg} \mathrm{dm}^{-3}$ [32]. The oxygen profiles presented in this paper show that oxygen conditions were improved in the surface layers of the three lakes, and that in the two unstratified lakes, the conditions deteriorated throughout the profile. Only a few authors have unequivocally confirmed the efficiency of aeration of the bottom waters $[14,19,26,33]$, e.g., by means of side stream saturation [24]. The high efficiency of this method was confirmed in a shallow drinking water reservoir (maximal depth $=9.3 \mathrm{~m}$ ) where concentration of dissolved oxygen was found to increase. Most authors conducting research on the effects of hypolimnion aeration found no sustainable improvement in oxygen conditions in the analysed lakes. Hypolimnion oxygenation conducted in five stratified lakes in Denmark over a period of 4 to 20 years resulted in a significant increase in hypolimnetic oxygen level in only one lake-the remaining four lakes still exhibited low mean levels in summer $\left(<2.2 \mathrm{mgO}_{2} \mathrm{dm}^{-3}\right)$ [21].

Pulverising aeration of waters is a method of lake restoration very often used in Poland. Even early studies showed the device should be equipped with an autonomous system designed to inactivate phosphorus [34]; therefore, chemical inactivation of phosphorus and biomanipulation have typically accompanied this activity. Monitoring tests of aerated water of the chosen lakes-Panieńskie, Trzęsiecko, Uzarzewskie and Swarzęckie—showed an improvement of water quality-reduction of CHL content, reduction of phosphorus budget available for phytoplankton in the vegetation period, and an increase of water transparency [26,35-37]. Authors of the cited papers found no improvement of DO of the hypolimnion zone; the exception was Lake Panieńskie, where improvement of DO was recorded [26]. The research by Wesołowski and Brysiewicz [38] carried out in Lake Starzyce showed that concentrations of ammonium-nitrogen, nitrate nitrogen and DO in water near the aerator did not differ from those in sites $200 \mathrm{~m}$ and $150 \mathrm{~m}$ away, which indicated similar abiotic conditions in the studied waters. As a result, bottom sediments remained an internal source of phosphate for the lake [39]. Similar results were obtained in Lake Swarzędz, in which, one year after the aerator was installed, there was no significant effect on the oxygenation of the hypolimnion zone, which could have resulted from the extremely large oxygen demand of the bottom sediments [37]. Therefore, when using pulverising aeration, attempts are typically made to undertake other restoration activities aimed at increasing the redox potential in the hypolimnion zone, e.g., by supplying this zone with cold ground water abundant in nitrates, transported from the springs with pipelines [36].

Having installed the aerator, in all the lakes under study, the recorded successive increase of the TN:TP ratio indicates that aeration may decrease phosphate in the water column by precipitation resorption. In three lakes-Barlineckie, Głebokie and Trzesiecko-the ratio was $>17$, so there was a change of the element limiting the growth of phytoplankton from nitrogen to phosphorus. 
Hence, the pulverising aeration of waters may shift the balance of phosphorus circulation at the water/sediment interphase towards deposition of phosphorus in the sediment. It should be noted that such changes may be connected with other protective measures taken as a part of the main remediating process-pulverising aeration. The first of these could be the reduction of allochthonous phosphorus sources. The implementation of the Water Framework Directive has caused changes in water and wastewater management in Poland. The total amount of the treated sewage increased by about $37.9 \%$ in the multi-year period between 1980 and 2007, whereas the amount of untreated sewage delivered to the environment decreased by as much as $83.4 \%$. The direct symptom of improvement in the situation was the decrease by about $59 \%$ of general phosphorus in the sewage drained into water in the multi-year period between 1995 and 2006 [40]. A second protective measure could be the chemical removal of phosphorus from the water column by means of coagulants [10-12]. The research of the bottom sediments of Lake Nowogardzkie conducted in the summer seasons of 2012-2014 showed significant reduction of $\mathrm{P}$ concentration in interstitial water-from $6.5 \mathrm{mgP} \mathrm{dm}^{-3}$ in 2012 to $3.3 \mathrm{mgP} \mathrm{dm}^{-3}$ in 2014. Internal P loading was at its highest in 2012, reaching over $24 \mathrm{mg} \mathrm{P} \mathrm{m}^{-2} \mathrm{~d}^{-1}$. After restoration treatment, up to $2 \mathrm{mg} \mathrm{P} \mathrm{m}^{-2} \mathrm{~d}^{-1}$ accumulation in sediments was noted [41]. Even the single Fe application still ensures the high $\mathrm{P}$ binding ability of the sediment, since Fe relocates towards the surface. Application of $\mathrm{Fe}$, particularly when external $\mathrm{P}$ loading has been reduced beforehand, is a suitable lake restoration tool for stabilising a new long-lasting equilibrium in lakes [42].

In the tree lakes under study-one stratified and five unstratified, there was a change of the element limiting the growth of phytoplankton from nitrogen to phosphorus. Limitations to algae development in the analysed lakes due to phosphorus were not confirmed by the analysis of particular values of TSI indices, the formulas of which are interrelated by linear regression models and should produce the same TSI value for a given combination of variable values. In cases where there is no such correspondence, the relationship between the partial indices (TSI(TP), TSI(CHL), TSI(SD) can be applied for the purpose of identification of prevailing conditions in the water reservoir limiting phytoplankton biomass $[43,44]$. The values of TSI calculated for the analysed lakes were either comparable, or the value of TSI(TP) was higher than one or two of the remaining indices. Such results indicate that in the analysed lakes, the development of phytoplankton biomass is limited by some factor other than phosphorus, e.g., zooplankton grazing, nitrogen, or the adverse effects of toxins. In the case of the lakes under analysis, this could very well stem from the remediation activities taken-aeration and coagulation. The restoration activities had no significant effect on the Carlson trophic state indices (TSI) in the study period, but only for the unstratified lakes; in the stratified lakes-Barlineckie and Zamkowe- - there was a significant decrease of TSI(TP).

The fact that hypolimnion aeration does not always affect the trophic state of a lake has been confirmed by many authors $[20,21,33,39,45,46]$ This was additionally confirmed by the experiment conducted in Lake Jyväsjärvi, where hypolimnion aeration was ceased, and which, in turn, had an extremely negative impact on the oxygen conditions in the hypolimnion, but showed no significant effect on the trophic state of the lake [20]. The results of multiannual studies on the efficiency of lake aeration seem to call into question the paradigm that oxygen controls the release of phosphorus from sediments $[47,48]$. Anaerobic sediments generally do not affect the productivity of lakes, and phosphorus is permanently deposited only in the deeper layers of the sediment [49]. Many notable authors have claimed that both the release of phosphorus and oxygen depletion result from the increased trophic state of a reservoir. Long-term study of phosphorus mobilisation from the bottom sediments indicates a vast array of mechanisms of phosphorus release from bottom sediments that are not controlled by redox conditions. One such mechanism is the enzymatic regeneration of orthophosphates, or the adsorption and chemical bonding of phosphorus with compounds of aluminium and calcium, which are controlled by a change in $\mathrm{pH}$ [48]. The results of the efficiency analysis of pulverising aeration of the seven lakes increase the concern for finding effective restoration methods for eutrophicated water bodies. Aeration helps alleviate some symptoms of eutrophication, but it does not contribute to solving the problem, especially in the case of unstratified lakes. 
Acknowledgments: This study was conducted on the basis of the data from the Inspection for Environmental Protection obtained under the State Environmental Monitoring with the use of funds from the Regional Environmental Protection and Water Management Fund in Szczecin.

Author Contributions: Siwek H. conceived and designed the research, partly analysed the data, and wrote the paper; Włodarczyk M. partly analysed the data; Czerniawski R. partly analysed the data.

Conflicts of Interest: The authors declare no conflict of interest.

\section{References}

1. Søndergaard, M.; Kristensen, P.; Jeppesen, E. Phosphorus release from resuspended sediment in shallow and wind-exposed Lake Arreso, Denmark. Hydrobiologia 1992, 228, 91-99. [CrossRef]

2. Wu, F.; Qing, H.; Wan, G. Regeneration of N, P and Si near the sediment/water interface of lakes from Southwestern China Plateau. Water Res. 2001, 35, 1334-1337. [CrossRef]

3. Jiang, X.; Jin, X.; Yao, Y.; Li, L.; Wu, F. Effects of oxygen on the release and distribution of phosphorus in the sediments under the light condition. Environ. Pollut. 2006, 141, 482-487. [CrossRef] [PubMed]

4. Lake, B.A.; Coolidge, K.M.; Norton, S.A.; Amirbahman, A. Factors contributing to the internal loading of phosphorus from anoxic sediments in six Maine, USA, lakes. Sci. Total Environ. 2007, 373, 534-541. [CrossRef] [PubMed]

5. Dittrich, M.; Koschel, R. Interactions between calcite precipitation (natural and artificial) and phosphorus cycle in the Hardwater Lake. Hydrobiologia 2002, 469, 49-57. [CrossRef]

6. Dittrich, M.; Gabriel, O.; Rutzen, C.; Koschel, R. Lake restoration by hypolimnetic $\mathrm{Ca}(\mathrm{OH})_{2}$ treatment: Impact on phosphorus sedimentation and release from sediment. Sci. Total Environ. 2011, 409, 1504-1515. [CrossRef] [PubMed]

7. Tandyrak, R.; Lossow, K.; Gawrońska, H. Long-term changes of environmental conditions in a lake resort by phosphorus inactivation. Limnol. Rev. 2001, 1, 263-270.

8. Jensen, H.S.; Reitzel, K.; Egemose, S. Evaluation of aluminum treatment efficiency on water quality and internal phosphorus cycling in six Danish lakes. Hydrobiologia 2015, 751, 189-199. [CrossRef]

9. Lewandowski, J.; Schauser, I.; Hupfer, M. Long term effects of phosphorus precipitations with alum in hypereutrophic Lake Süsser See (Germany). Water Res. 2003, 37, 3194-3204. [CrossRef]

10. Deppe, T.; Benndorf, J. Phosphorus reduction in a shallow hypereutrophic reservoir by in-lake dosage of ferrous iron. Water Res. 2002, 36, 4525-4534. [CrossRef]

11. Perkins, R.G.; Underwood, G.J.C. The potential for phosphorus release across the sediment-water interface in an eutrophic reservoir dosed with ferric sulphate. Water Res. 2001, 35, 1399-1406. [CrossRef]

12. Zeng, L.; Li, X.M. Adsorptive removal of phosphate from aqueous solutions using iron oxide tailings. Water Res. 2008, 38, 1318-1326. [CrossRef] [PubMed]

13. Haghseresht, F.; Wang, S.; Do, D.D. A novel lanthanum-modified bentonite, Phoslock, for phosphate removal form waste waters. Appl. Clay Sci. 2009, 46, 369-375. [CrossRef]

14. Gawrońska, H.; Brzozowska, R.; Grochowska, J.; Lossow, K. Possibilities to reduce Loading to Lake Water by Artificial Aeration. Pol. J. Environ. Stud. 2003, 12, 171-179.

15. Klapper, H. Technologies for lake restoration. J. Limnol. 2003, 62, 73-90. [CrossRef]

16. Hickey, C.W.; Gibbs, M.M. Lake sediment phosphorus release management-Decision support and risk assessment Framework. N. Z. J. Mar. Freshw. Res. 2009, 43, 819-856. [CrossRef]

17. Ashley, K.I. Recent advances in hypolimnetic aeration design. Verh. Int. Ver. Limnol. 2000, 27, $2256-2260$. [CrossRef]

18. Ashley, K.I.; Mavinic, D.S.; Hall, K.J. Effect of orfice diameter, depth of air injection, and air flow rate on oxygen transfer in a pilot-scale, full lift, hypolimnetic aerator. Can. J. Civ. Eng. 2009, 36, 137-147. [CrossRef]

19. Prepas, E.E.; Burke, J.M. Effects of hypolimnetic oxygenation on water quality in Amisk Lake, Alberta, a deep, eutrophic lake with high internal phosphorus loading rates. Can. J. Fish. Aquat. Sci. 1997, 54, 2111-2120. [CrossRef]

20. Kuha, J.K.; Palomäki, A.H.; Keskinen, J.T.; Karjalainen, J.S. Negligible effect of hypolimnetic oxygenation on the trophic state of lake Jyväsjärvi, Finland. Limnologica 2016, 58, 1-6. [CrossRef] 
21. Liboriussen, L.; Søndergaard, S.; Jeppesen, E.; Thorsgaard, I.; Grünfeld, S.; Jakobsen, T.S.; Hansen, K. Effects of hypolimnetic oxygenation on water quality: Results from five Danish lakes. Hydrobiologia 2009, 625, 157-172. [CrossRef]

22. Salmi, P.; Malin, I.; Salonen, K. Pumping of epilimnetic water into hypolimnion improves oxygen but not necessarily nutrient conditions in a lake recovering from eutrophication. Inland Waters 2014, 4, 425-434. [CrossRef]

23. Beutel, M.W.; Horne, A.J. A review of the effects of hypolimnetic oxygenation on lake and reservoir water quality. Lake Reserv. Manag. 1999, 15, 285-297. [CrossRef]

24. Gerling, A.B.; Browne, R.G.; Gantzer, P.A.; Mobley, M.H.; Little, J.C.; Carey, C.C. First report of the successful operation of a side stream supersaturation hypolimnetic oxygenation system in a eutrophic, shallow reservoir. Water Res. 2014, 67, 129-143. [CrossRef] [PubMed]

25. Konieczny, R.; Pieczyński, L. Reclamation possibility of Westpomerania Region lakes using pulverizing aeration technology. Acta Agrophys. 2006, 7, 947-957.

26. Osuch, E.; Podsiadłowski, S. Efficiency of pulverizing aeration on Lake Panieńskie. Limnol. Rev. 2012, 12, 139-145. [CrossRef]

27. Matkowski, G.; Podsiadłowski, S. Pulverizer aerating of water in Lake Stare Resko. In Protection and Reclamation of lakes, Proceedings of the 5th Scientific Conference, Grudziadz, Poland, 1-13 May 2004; Wiśniweski, R., Jankowski, J., Eds.; Association of Sanitary Engineers and Technicians: Toruń, Poland, 2004; pp. 151-158.

28. International Organization for Standardization. ISO 5814:2012. Water Quality-Determination of Dissolved Oxygen-Electrochemical Probe Method; ISO: Geneva, Switzerland, 2012.

29. Hermanowicz, W.; Dojlido, J.; Dożańska, W. Physico-Chemical Examination of Water and Sewagei; Arkady Publishing: Warsaw, Poland, 1999; p. 556, ISBN 9788321340678.

30. Forsberg, C.; Ryding, S.O. Eutrophication parameters and trophic state indices in 30 Swedish waste-receiving lakes. Arch. Hydrobiol. 1980, 89, 189-207.

31. Carlson, R.E. A trophic state index for lakes. Limnol. Oceanogr. 1977, 22, 361-369. [CrossRef]

32. Wyman, B.; Stevenson, L.H. Dictionary of Environmental Science; Facts on File, Inc.: New York, NY, USA, 1991.

33. Moore, B.C.; Cross, B.K.; Beutel, M.; Dent, S.; Preece, E.; Swanson, M. Newman Lake restoration: A case study Part III. Hypolimnetic oxygenation. Lake Reserv. Manag. 2012, 28, 311-327. [CrossRef]

34. Kaczorowska, E.; Podsiadłowski, S. Pulverizing aeration as a method of lakes arestoration. In Proceedings of the EGU General Assembly, Vienna, Austria, 22-27 April 2012; Volume 14, EGU2012-11355-1.

35. Heese, T.; Wilk-Woźniak, E.; Żurek, R.; Kaczorkiewicz, M.; Szmidt, R.; Arciszewski, M.; Pikuła, K.; Wojcieszonek, A.; Chrzczonowicz, H.; Zakościelna, A. The estimation of the ecological effect for restoration Trzesiecko Lake in the period between 2005 and 2012. In Protection and Reclamation of Lakes, Proceedings of the VII Scientific Conference, Przysiek, Poland, 7-9 June 2013; Wiśniweski, R., Ed.; Association of Sanitary Engineers and Technicians: Toruń, Poland, 2013; pp. 65-80.

36. Dondajewska, R.; Gołdyn, R.; Podsiadłowski, S.; Kozak, A.; Kowalczewska-Madura, K.; Koźlik, K. Changes in water quality of Lake Uzarzeswkie as a result of restoration water treatment. In Protection and Reclamation of Lakes, Proceedings of the VII Scientific Conference, Przysiek, Poland, 7-9 June 2013; Wiśniweski, R., Ed.; Association of Sanitary Engineers and Technicians: Toruń, Poland, 2013; pp. 47-54.

37. Osuch, E.; Podsiadłowski, S.; Przybył, J. Lake Swarzędzkie restoration. In Protection and Reclamation of Lakes, Proceedings of the VII Scientific Conference, Przysiek, Poland, 7-9 June 2013; Wiśniweski, R., Ed.; Association of Sanitary Engineers and Technicians: Toruń, Poland, 2013; pp. 169-176.

38. Wesołowski, P.; Brysiewicz, A. The effect of pulverising aeration on changes in the oxygen and nitrogen concentrations in water of Lake Starzyc. J. Water Land Dev. 2015, 25, 31-36. [CrossRef]

39. Siwek, H.; Wesołowski, P.; Brysiewicz, A. Content of phosphorus and selected metals in bottom sediments of Starzyc Lake under conditions of pulverizing water aeration. J. Elementol. 2014, 19, 1099-1108. [CrossRef]

40. Wałęga, A.; Chmielowski, K.; Satora, S. Water and wastewater management condition in Poland regarding Water Framework Directive implementation. Infrastruct. Ecol. Rural Areas 2009, 4, 57-72.

41. Dondajewska, R. Internal phosphorus loadin from bottom sediments in restored Nowogardzkie Lake. In Protection and Reclamation of Lakes, Proceedings of the IX Scientific Conference, Przysiek, Poland, 9-11 June 2015; Wiśniweski, R., Ed.; Association of Sanitary Engineers and Technicians: Torun, Poland, 2015; pp. 57-64.

42. Kleeberg, A.; Köhler, A.; Hupfer, M. How effectively does a single or continuous iron supply affect the phosphorus budget of aerated lakes? J. Soils Sediments 2012, 12, 1593-1603. [CrossRef] 
43. Carlson, R.E.; Simpson, J. A Coordinators Guide to Volunteer Lake Monitoring Methods; North American Lake Management Society: Madison, WI, USA, 1996; Volume 96.

44. Havens, K.E. Using Trophic State Index (TSI) values to draw inferences regarding phytoplankton li miting factors and seston composition from routine water quality monitoring data. Korean J. Limnol. 2000, 33, 187-196.

45. Gächter, R.; Schweiz, Z. Lake restoration. Why oxygenation and artificial mixing cannot substitute for a decrease in the external phosphorus loading. Swiss J. Hydrol. 1987, 49, 170-185. [CrossRef]

46. Horppila, J.; Holmroos, H.J.; Niemisto, J.; Massa, I.; Nygren, N.; Schönach, P.; Tapio, P.; Tammeorg, O. Variations of internal phosphorus loading and water quality in a hypertrophic lake during 40 years of different management efforts. Ecol. Eng. 2017, 103, 264-274. [CrossRef]

47. Gächter, R.; Müller, B. Why the phosphorus retention of lakes does not necessarily depend on the oxygen supply to their sediment surface. Limnol. Oceanogr. 2003, 48, 929-933. [CrossRef]

48. Hupfer, M.; Lewandowski, J. Oxygen Controls the Phosphorus Release from Lake Sediments-A Long-Lasting Paradigm in Limnology. Int. Rev. Hydrobiol. 2008, 93, 415-432. [CrossRef]

49. Tammeorg, O.; Möls, T.; Niemistö, J.; Holmroos, H.; Horppila, J. The actual role of oxygen deficit in the linkage of the water quality and benthic phosphorus release: Potential implications for lake restoration. Sci. Total Environ. 2017, 599-600, 732-738. [CrossRef] [PubMed]

(C) 2018 by the authors. Licensee MDPI, Basel, Switzerland. This article is an open access article distributed under the terms and conditions of the Creative Commons Attribution (CC BY) license (http:/ / creativecommons.org/licenses/by/4.0/). 